\title{
The influence of Internet on traditional enterprise marketing
}

\author{
Zhao Fengping \\ Ningxia Institute of Science and Technology, China,753000
}

Keywords: Internet economy; Traditional enterprises; marketing

Abstract: With the rapid development of Internet economy, Chinese traditional enterprises have been greatly influenced and impacted. Traditional enterprises are faced with major problems in marketing, operation and logistics. This paper mainly analysis the problems in marketing. The paper first analysis the development background and trend of Internet economy, and then points out the influence of e-commerce development on traditional enterprises. Finally, it puts forward the rationalization proposal of the improvement under the Internet economy.

\section{Introduction}

China has been the world's largest Internet user for nearly a decade. China has become a truly global cyber power. China has built the world's largest broadband network infrastructure, providing strong support and solid foundation for the implementation of enterprise Internet transformation and upgrading. According to relevant statistics, the number of Internet users in China has reached 7.1 billion by 2016, more than 50\% of the Internet penetration rate. China's Internet economic platforms have shown strong momentum, sparking a wave of e-commerce development. Such as taobao, Jingdong, suning and other e-commerce platforms. Take taobao's "Double Eleven" event sales for example, we can see the prosperity of China's Internet economy.

Table 1. "Double Eleven" event sales of taobao

\begin{tabular}{c|ccc}
\hline Year & Sales (yuan) & Year & Sales (yuan) \\
\hline 2013 year & 35 billion yuan & 2016 year & 120.7 billion yuan \\
2014 year & 57.1 billion yuan & 2017 year & 168.2 billion yuan \\
2015 year & 91.2 billion yuan & & \\
\hline
\end{tabular}

\section{The influence of Internet economy on traditional enterprise marketing}

\subsection{The impact of marketing model}

The marketing of traditional enterprises consumes huge human and material resources. In addition to infrastructure, its operation also requires warehouses, shop fronts and other costs of economic property. However, we open up new channels of distribution through the Internet economy, and marketing costs are very low. By releasing product and service information on the 
Internet platform, providing different types of products for different customer groups and classifying their different functions, sales can be effectively increased. Traditional enterprise sales channel depends on intermediary structure. There are many obstacles between producer and consumer in terms of geographical location and time transition. Such disadvantages as low efficiency, multiple links and product overstocking will increase operating costs. The Internet economy gives manufacturers new channels for production and sales. The role of traditional commercial intermediaries is gradually reduced, and enterprises gradually reduce their dependence on intermediaries. The traditional "vendor-wholesale-retail-customer" model is gradually simplified as "vendor-customer". The reduction of middlemen has greatly reduced the cost and increased efficiency.

\subsection{The impact of marketing module}

The Internet not only has an impact on the marketing mode, but also on various modules and links in marketing. First, Internet technology has an impact on marketing probes. Internet sales raise the status of consumers. Consumer book goods through the Internet, and merchants receive, provide and collect market information in the process. The traditional marketing probe is mainly aimed at the whole consumer group, while the Internet economy focuses on individual differences. Second, the Internet has an impact on marketing strategy. The Internet marketing strategy is no longer targeted at groups, but subdivided into people. The marketing plan is customized according to their different characteristics, which strengthens the communication between customers and enterprises. With the increasing demand of consumers, personalized products can attract consumers' attention, which strengthens the market positioning of enterprises. Third, the Internet has an impact on the marketing mix.

The Internet economy has removed most of the distribution links, and goods are directly distributed in logistics. In addition, consumers can independently choose products, they have the right to decide on the design and configuration of products.

\subsection{Increasing the transparency of enterprise marketing information}

In the Internet era, more attention is paid to communication, which increases the transparency of information in enterprise marketing. The price of goods is determined by the market. Merchants and customers can use Internet technology to understand the market price, so there is not much difference in the price of the same goods. In addition, the rights and interests of consumers are guaranteed, and the one-to-one marketing model becomes the demand of the public. The development of Internet economy improves the interactivity of marketing, which enables consumers and merchants one-to-one communication.

\subsection{The impact of marketing time}

The rapid development of Internet economy breaks the time limit of marketing in the past. The traditional face-to-face marketing concept follows the natural schedule first, which is basically limited to the eight-hour working time during the day. However, the Internet economy has achieved round-the-clock marketing, and customers can help complete transactions at any time. The "double eleven" curtain is opened at zero, big data updates of transactions are measured in seconds, and various carnival activities are revealed at every zero. Traditional marketing cannot deliver 24-hour marketing. In addition, in Internet economic marketing, buyers and sellers are not limited by space. Where network technology reaches, the space for Internet marketing reaches. 


\section{The discussion on marketing strategies of traditional enterprises}

\subsection{Implement online and offline marketing model}

Internet marketing is an unprecedented business opportunity for traditional enterprises as well as a fierce competition challenge. Traditional enterprises should not only make strategic decisions, but also ensure the implementation of tactics. Traditional enterprises should fully meet the needs of consumers and re-examine the core values in their marketing activities. And then make and adjust the Internet marketing strategy. Traditional enterprises should fully combine their own advantages and network characteristics, unify online and offline, and realize strategic marketing. First, the online and offline strategic planning of the price system. Traditional enterprises should plan and manage the overall price system according to market and channel segmentation. Only in this way can the price system be stable and the conflict between online and offline channels be avoided. Second, reasonable coordination of operational organizations. Traditional enterprises should reasonably set up departments. In the face of the national common consumer group, they must properly allocate online and offline channels and divide models. Which is because while Internet marketing is independent of traditional sales departments, it is possible to share services and support from a financial department and a Marketing Department. Third, strengthen the adjustment of logistics distribution services. Traditional enterprises should make full use of the existing logistics system, including their own logistics, distribution agents, and increase the third-party logistics cooperation mode. Only by building an integrated logistics delivery service system can we reduce logistics costs and improve corporate profits.

\subsection{Improve the accuracy of Internet marketing}

Internet marketing data mainly comes from the analysis tools of enterprise operation system and Internet platform. Such as marketing management system, ERP system, taobao platform, store operation and traffic analysis tools. The quantification and information of Internet data can guide traditional enterprises to make reasonable pricing, grasp inventory and optimize process. Which provides the enterprise with the strategic decision basis. At the same time, marketing data can also improve customer maintenance efficiency and marketing accuracy. Traditional enterprises can improve the transaction conversion rate of online stores through accurate positioning of customer groups, accurate search and advertising promotion.

\subsection{Pay attention to Internet talent recruitment}

The mode of "traditional marketing talents + Internet professionals" is the correct way for traditional enterprises to enter the Internet marketing mode. Traditional enterprises must build a professional Internet marketing team to ensure the normal operation, scientific decision-making and strategic implementation of Internet marketing. On the one hand, traditional enterprises should select talents who are familiar with the operation of their products, and let them take charge of Internet product positioning and promotion planning. On the other hand, enterprises should recruit professional talents in Internet technology and management. And let them be responsible for the operation of online stores and brand promotion. The team of marketing talents and technical talents should be fully integrated, which should not only use the Internet to do marketing, but also maintain the market acuity and execution of traditional marketing. Only when traditional enterprises operate orderly in Internet marketing can they achieve their target performance quickly. 


\subsection{Value the interaction between merchants and consumers}

Traditional enterprises can interact with potential consumers through Internet platforms such as WeChat public account and enterprise micro blog. Traditional enterprises can attract and guide fans by means of marketing, themed activities, interest driven, etc. Traditional enterprises can enhance mutual understanding and trust through activities such as "group" consumer experience. In these ways, we can gain the goodwill of consumers. Through consumer interaction, "potential group" can gradually form "potential market", guide "potential group" consumption, and form "group economy". Driven by interests and interests, "group members" can spread information across groups and circles, and expand market influence. In this way we can achieve this goals which are online diversion and attracting consumption. Enterprises should be responsible for "group" operation, and at the same time develop key potential customers to achieve customer upgrading. The interaction between merchants and consumers is helpful to the Internet marketing and promotion of traditional enterprises.

\subsection{Strengthen after-sales information collection and expand brand influence}

An obvious feature of Internet marketing is the effective interaction between enterprises and consumers. Through Internet marketing, traditional enterprises should pay attention to the collection of feedback information, such as consumer demand and opinions, and provide online solutions and services. Traditional enterprises should regard Internet marketing and brand communication as a whole, and promote products and expand brand awareness while selling. The consumers' opinions can promote the improvement and upgrading of products and services. This is of great help to improve the accuracy of the implementation of Internet promotion strategies. At the same time, consumers' five-star praise and word of mouth can promote online transactions and enhance online brand competitiveness. So, when traditional enterprises sell Internet, they must strengthen the after-sale information collection.

\section{Conclusions}

In the Internet era, enterprise marketing has undergone a great transformation. As an innovative enterprise marketing model, Internet marketing has an important impact on the total marketing model, various marketing links and the transparency of information. The Internet marketing model has played a positive role in the development of enterprises. Traditional enterprises should recognize the problems arising from the use of the Internet marketing. We need to manage effectively from various aspects to achieve the goal of improving marketing.

\section{References}

[1] Humphrey J. Schmitz H. Governance and Upgrading: Linking Industrial Cluster and Global Value Chain. IDS Working Paper, 2010.

[2] D. J. Teece, G Pisano, Dynamic Capabilities and Strategic Management, Strategic Management Journal,2007.

[3] Gary Gereffi. International Trade and Industrial Upgrading in the Apparel Commodity Chains[J].Journal of International Economics,1999.

[4] Humphrey J. Schmitz H.: Governance and Upgrading: Linking Industrial Cluster and Global Value Chain. IDS Working Paper, 2010.

[5] Poon, T. S-C. Beyond the Global Production Networks: a Case of Further Upgrading of Taiwan's Information Technology Industry, Int. J. Technology and Globalisation, 2014. 